\title{
Antiphospholipid antibodies (aPL) in systemic lupus erythematosus. Are they specific tools for the diagnosis of aPL syndrome?
}

\author{
Anna Ghirardello, Andrea Doria, Amelia Ruffatti, Angela Maria Rigoli, Patrizia Vesco, \\ Antonia Calligaro, Pier Franca Gambari
}

\begin{abstract}
Objective - Antiphospholipid antibody (aPL) specificity for aPL-related events was evaluated in systemic lupus erythematosus (SLE).

Methods-A study was carried out on 105 patients affected with SLE comparing the prevalence of lupus anticoagulant (LA) and IgG and IgM anticardiolipin antibodies (aCL) between patients with and without features of antiphospholipid syndrome (APS). Antiphospholipid antibody profile was subsequently evaluated in the aPL positive patients with and without aPL-related events, thus excluding the patients with complications of APS possibly due to factors other than aPL.

Results-LA showed a strong association with thrombosis and livedo reticularis, and IgG aCL with thrombosis and neurological disorders, while no clinical features were associated with IgM aCL. A considerable number of aPL positive patients with no aPL-related manifestations was also observed, suggesting the low specificity of aPL assays $(54 \cdot 4 \%)$. When studying the $60 \mathrm{aPL}$ positive patients, LA was specific $(91 \cdot 3 \%)$ for the diagnosis of aPL-related thrombosis, whereas aCL were not specific, although IgG aCL mean levels were higher in patients with arterial thrombosis than in those without APS features.
\end{abstract}

Conclusions-LA but not aCL positivity is a specific tool for the diagnosis of thrombotic complications due to aPL in SLE.

(Ann Rheum Dis 1994; 54: 140-142)

Padova, Italy

Division of

Rheumatology

A Ghirardello

A Doria

A Ruffatti

$P$ Vesco

A Calligaro

P F Gambari

Department of Clinical Medicine

A M Rigol

Correspondence to:

Andrea Doria and Anna

Ghirardello,

Cattedra e Divisione di

Reumatologia

Policlinico Universitario

via Giustiniani 2,

35128 Padova, Italy.

Accepted for publication

13 October 1993 pregnancy loss. ${ }^{1}$ Moreover, other manifestations including livedo reticularis, various neurological disorders, thrombocytopenia and positive direct Coomb's test can occur. ${ }^{1}$ However, aPL may also be found in a large spectrum of other autoimmune and non-
Antiphospholipid antibodies (aPL), such as upus anticoagulant (LA) and anticardiolipin markers of the antiphospholipid syndrome (APS). ${ }^{1}$ In this condition aPL are found in association with venous and/or arterial autoimmune diseases ${ }^{2} 3$ and characteristically in systemic lupus erythematosus (SLE). ${ }^{4}{ }^{5}$ The detection of aPL has been proposed as a predictive and specific tool for the diagnosis of APS in SLE. ${ }^{5}$ The clinical significance of aPL in SLE patients, however, has not yet been well established, ${ }^{6}$ partly because of a limited standardisation method applied in aPL detection. ${ }^{4} 8$

First, we studied LA activity and IgG and IgM aCL prevalences in SLE patients with and without clinical features of APS, to discover whether differences in aPL prevalence and characteristics could account for different clinical pictures. We then evaluated aPL profile in aPL positive SLE patients with and without aPL-related manifestations, thus excluding patients with complications of APS due to factors other than aPL. Such evaluation enabled us to a better definition of LA and aCL specificity for the occurrence of aPL-related events within SLE.

\section{Patients and methods}

Serum and plasma samples of 105 patients affected with SLE (ARA criteria) were tested for aPL. There were 97 women and eight men, mean age $35 \cdot 7$ years, range $14-79$ years. At the time of blood sampling, clinical history, physical examination and routine blood analysis were obtained from all patients to evaluate the presence of features related to aPL, particularly venous and/or arterial thrombosis, recurrent fetal loss, thrombocytopenia (platelet count below $100000 / \mu l$ in two different occasions), neurological disorders and livedo reticularis. We excluded eight patients treated with high doses of steroids (prednisone $\geqslant 20 \mathrm{mg} /$ daily) or immunosuppressants due to reports on the suppressive effects of this therapy on LA activity and, to a lesser extent, on aCL. ${ }^{5910}$ None of the patients were receiving thrombosis-inducing drugs such as oral contraceptives or being treated with heparin.

LA was determined by the diluted Russell viper venom time according to Thiagarajan et al. ${ }^{11}$ Serum IgG and IgM aCL were measured by an enzyme-linked immunosorbent assay (ELISA) as described by Gharavi et al. ${ }^{12}$ Results were expressed as GPL and MPL obtained from the standard curve of each plate. The mean value +4 standard deviations of 100 
Table 1 Frequency (percentage) of aPL, LA, IgG and IgM aCL in 105 SLE patients in relation to aPL syndrome manifestations.

\begin{tabular}{|c|c|c|c|c|c|c|c|c|c|c|c|c|}
\hline \multirow[b]{2}{*}{ n pts } & \multicolumn{2}{|c|}{$\begin{array}{l}\text { aPL-related } \\
\text { manifestations }\end{array}$} & \multicolumn{2}{|c|}{ Thrombosis } & \multicolumn{2}{|c|}{ Fetal loss $\$$} & \multicolumn{2}{|c|}{$\begin{array}{l}\text { Thrombo- } \\
\text { cytopenia }\end{array}$} & \multicolumn{2}{|l|}{$\begin{array}{l}\text { CNS } \\
\text { disorders }\end{array}$} & \multicolumn{2}{|c|}{$\begin{array}{l}\text { Livedo } \\
\text { reticularis }\end{array}$} \\
\hline & $\begin{array}{l}\text { No } \\
57\end{array}$ & $\begin{array}{l}\text { Yes } \\
48\end{array}$ & $\begin{array}{l}\text { No } \\
87\end{array}$ & $\begin{array}{l}\text { Yes } \\
18\end{array}$ & $\begin{array}{l}\text { No } \\
45\end{array}$ & $\begin{array}{l}\text { Yes } \\
2\end{array}$ & $\begin{array}{l}\text { No } \\
89\end{array}$ & $\begin{array}{l}\text { Yes } \\
16\end{array}$ & $\begin{array}{l}\text { No } \\
85\end{array}$ & $\begin{array}{l}\text { Yes } \\
20\end{array}$ & $\begin{array}{l}\text { No } \\
96\end{array}$ & $\begin{array}{l}\text { Yes } \\
9\end{array}$ \\
\hline $\begin{array}{l}\text { aPL } \\
\text { LA } \\
\text { IgG aCL } \\
\text { IgM aCL }\end{array}$ & $\begin{array}{c}45 \cdot 6^{M} \\
3 \cdot 5^{\wedge} \\
40 \cdot 3^{\wedge} \\
15 \cdot 8\end{array}$ & $\begin{array}{l}70 \cdot 8 \\
14 \cdot 6 \\
64 \cdot 6 \\
37 \cdot 5\end{array}$ & $\begin{array}{c}52 \cdot 9 \\
4 \cdot 6 c \\
46 \cdot 0^{\chi} \\
25 \cdot 3\end{array}$ & $\begin{array}{l}77 \cdot 7 \\
27 \cdot 8 \\
77 \cdot 8 \\
27 \cdot 8\end{array}$ & $\begin{array}{r}55 \cdot 5 \\
8 \cdot 9 \\
46 \cdot 7 \\
26 \cdot 7\end{array}$ & $\begin{array}{l}0.0 \\
0.0 \\
0.0 \\
0.0\end{array}$ & $\begin{array}{l}55 \cdot 0 \\
10 \cdot 1 \\
49 \cdot 4 \\
23 \cdot 6\end{array}$ & $\begin{array}{r}68 \cdot 7 \\
0 \cdot 0 \\
62 \cdot 5 \\
37 \cdot 5\end{array}$ & $\begin{array}{l}51 \cdot 8^{\star} \\
7 \cdot 0^{\star \star} \\
45 \cdot 8^{\star \star} \\
23 \cdot 5\end{array}$ & $\begin{array}{l}80 \cdot 0 \\
15 \cdot 0 \\
75 \cdot 0 \\
35 \cdot 0\end{array}$ & $\begin{array}{c}53 \cdot 1^{M} \\
6 \cdot 2^{\star \star} \\
48 \cdot 9 \\
23 \cdot 0\end{array}$ & $\begin{array}{r}100 \cdot 0 \\
33 \cdot 3 \\
77 \cdot 8 \\
55 \cdot 5\end{array}$ \\
\hline
\end{tabular}

$\$$ Out of 47 female patients who experienced pregnancy.

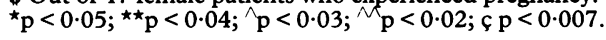

Table 2 Prevalence (percentage) of $L A, \operatorname{IgG}$ and IgM aCL in 60 aPL positive patients with SLE with and without clinical manifestations of aPL syndrome.

\begin{tabular}{|c|c|c|c|c|c|c|c|c|c|c|c|c|}
\hline \multirow[b]{2}{*}{ n pts } & \multicolumn{2}{|c|}{ Thrombosis } & \multicolumn{2}{|c|}{$\begin{array}{l}\text { Venous } \\
\text { thrombosis }\end{array}$} & \multicolumn{2}{|c|}{$\begin{array}{l}\text { Arterial } \\
\text { thrombosis }\end{array}$} & \multicolumn{2}{|c|}{$\begin{array}{l}\text { Thrombo- } \\
\text { cytopenia }\end{array}$} & \multicolumn{2}{|c|}{$\begin{array}{l}\text { CNS } \\
\text { disorders }\end{array}$} & \multicolumn{2}{|c|}{$\begin{array}{l}\text { Livedo } \\
\text { reticularis }\end{array}$} \\
\hline & $\begin{array}{l}\text { No } \\
46\end{array}$ & $\begin{array}{l}\text { Yes } \\
14\end{array}$ & $\begin{array}{l}\text { No } \\
49\end{array}$ & $\begin{array}{l}\text { Yes } \\
11\end{array}$ & $\begin{array}{l}\text { No } \\
55\end{array}$ & $\begin{array}{l}\text { Yes } \\
5\end{array}$ & $\begin{array}{l}\text { No } \\
49\end{array}$ & $\begin{array}{l}\text { Yes } \\
11\end{array}$ & $\begin{array}{l}\text { No } \\
44\end{array}$ & $\begin{array}{l}\text { Yes } \\
16\end{array}$ & $\begin{array}{l}\text { No } \\
51\end{array}$ & $\begin{array}{l}\text { Yes } \\
9\end{array}$ \\
\hline $\begin{array}{l}\text { LA } \\
\text { IgG aCL } \\
\text { IgM aCL }\end{array}$ & $\begin{array}{l}8 \cdot 7^{\star} \\
87 \cdot 0 \\
48 \cdot 0\end{array}$ & $\begin{array}{r}35 \cdot 7 \\
100 \cdot 0 \\
37.5\end{array}$ & $\begin{array}{l}12 \cdot 3 \\
87 \cdot 7 \\
47 \cdot 0\end{array}$ & $\begin{array}{r}27 \cdot 3 \\
100 \cdot 0 \\
36 \cdot 4\end{array}$ & $\begin{array}{l}11 \cdot 0^{\star \star} \\
89 \cdot 1 \\
45 \cdot 4\end{array}$ & $\begin{array}{r}60 \cdot 0 \\
100 \cdot 0 \\
40 \cdot 0\end{array}$ & $\begin{array}{l}18 \cdot 4 \\
89 \cdot 8 \\
43 \cdot 0\end{array}$ & $\begin{array}{r}0.0 \\
90.9 \\
54.5\end{array}$ & $\begin{array}{l}13 \cdot 6 \\
88 \cdot 6 \\
45 \cdot 4\end{array}$ & $\begin{array}{l}18 \cdot 7 \\
93 \cdot 7 \\
43 \cdot 7\end{array}$ & $\begin{array}{l}11 \cdot 8 \\
92 \cdot 1 \\
43 \cdot 1\end{array}$ & $\begin{array}{l}33 \cdot 3 \\
77 \cdot 8 \\
55 \cdot 5\end{array}$ \\
\hline
\end{tabular}

${ }^{\star} \mathrm{p}=0.04 ;{ }^{\star \star} \mathrm{p}=0.022$.

healthy subjects (13 GPL and $15 \mathrm{MPL}$ ) was considered as cut-off for both IgG and IgM aCL levels.

Association of aPL and clinical manifestations was tested by Chi-square analysis of contingency tables. Mean (SD) differences of aCL levels, between the groups were determined by $t$ test of independent samples.

\section{Results}

Raised levels of aPL were detected in the sera of 60 of 105 patients with SLE (57.1\%): IgG $\mathrm{aCL}$ in $54(51.4 \%)$, IgM aCL in $27(25.7 \%)$, both IgG and IgM aCL in $21(20.0 \%)$. LA was found in nine patients $(8 \cdot 6 \%)$, always associated with aCL positivity.

Eighteen patients $(17 \cdot 1 \%)$ had a history of at least one thrombotic event or episodes of vascular occlusions at the time of aPL detection: 12 had venous occlusions at lower and upper limbs, and abdominal veins in one case, 3 had arterial thrombosis (myocardial infarction, retinal and renal artery occlusions, respectively), and 3 had both types of

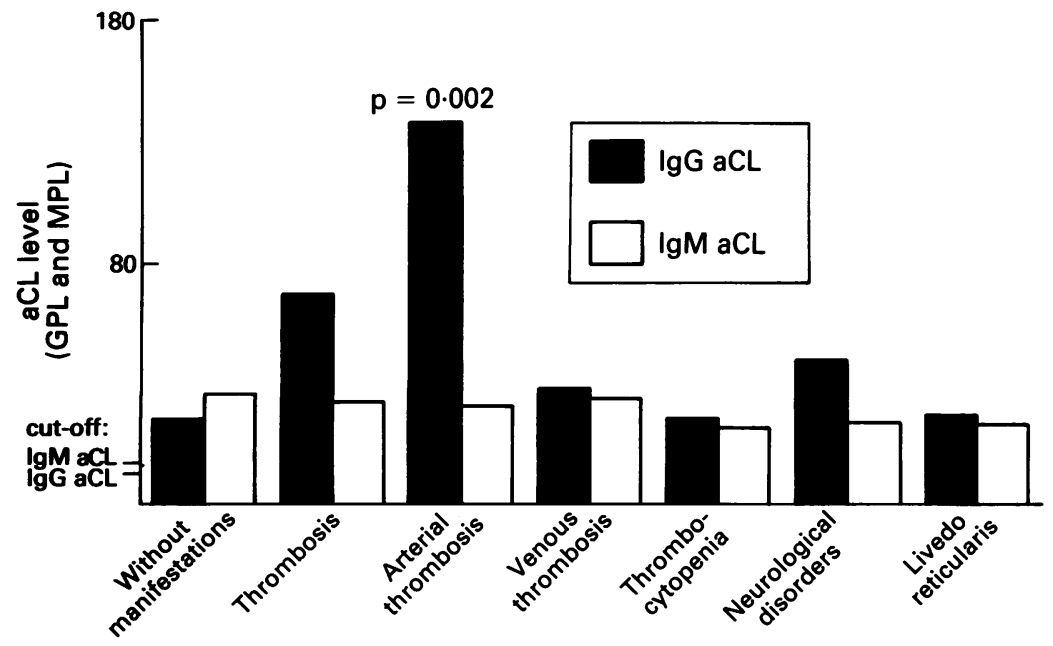

Mean levels of IgG and IgM aCL in aPL positive patients with and without aPL syndrome manifestations. complications. Of 47 female patients who experienced pregnancy, only two $(4 \cdot 2 \%)$ had had two episodes each of fetal loss, eight $(17 \%)$ had pre-term delivery and two (4\%) preeclampsia. Sixteen patients $(15 \cdot 2 \%)$ had thrombocytopenia; $20(19.0 \%)$ suffered from various neuropsychiatric disorders such as transient ischaemic attacks $(n=1)$, chorea $(n=1)$, epilepsy $(n=8)$, amaurosis fugax $(n=2)$, migraine $(n=1)$, psychosis $(n=7)$, and acute organic syndrome $(n=2)$; two patients had more than one neurological feature. Nine $(98 \cdot 6 \%)$ had livedo reticularis. Sixteen patients $(15 \cdot 2 \%)$ presented more than one manifestation. Fifty seven patients $(54.3 \%)$ did not show any of the disorders mentioned.

Frequency of aPL, LA, IgG and IgM aCL in SLE patients with and without aPL-related manifestations is reported in table 1 . No difference in frequencies of pre-term delivery and pre-eclampsia between aPL positive and negative patients was found.

Frequency of LA, IgG and IgM aCL and mean IgG and IgM aCL levels in the $60 \mathrm{aPL}$ positive patients with SLE, with and without clinical manifestations of APS, are shown in table 2 and the figure.

\section{Discussion}

The frequency of aCL in our patients was similar to that reported by other authors. ${ }^{691314}$ The frequency of LA was lower than the average reported by Love $e t a l,{ }^{4}$ but similar to that found by some authors. ${ }^{4}$ Both aCL and LA detection are influenced by differences in sensitivity and specificity of methods applied, ${ }^{815}$ in the definition of the positive/negative cut off points ${ }^{8}$ and in patient selection criteria. ${ }^{45}$

Our data (table 1) show that thrombosis was strongly associated with LA activity and, to a lesser extent, with IgG aCL positivity. Neurological symptoms were related to IgG $\mathrm{aCL}$ and livedo reticularis to LA. Recurrent 
fetal loss and thrombocytopenia did not correlate with LA or aCL positivity. Recurrent fetal loss was an uncommon feature in our patients probably because aspirin was used at low doses in risk pregnancies. Previously, no direct relationship with aPL, both in SLE and non-SLE patients, has been reported in thrombocytopenia. ${ }^{4}$ No selected manifestations were significantly correlated with $\operatorname{IgM} \mathrm{aCL}$; this agrees with a previous report. ${ }^{13}$ Conversely, there was a considerable number of aPL positive patients with none of the selected manifestations (table 1): two were both positive for LA and aCL. Similar findings have been reported ${ }^{15}$ but, as yet, have not been clarified. Such observations could suggest that methods for aPL detection are sensitive but not specific for identifying the subset of patients with SLE at risk for aPL-related complications.

Thus we investigated the clinical significance of LA and aCL characteristics (isotype and level) within the group of aPL positive SLE patients (table 2, figure). Our study group was better defined by excluding patients who did not have the criteria for APS, that is, patients with selected manifestations of APS not related to aPL positivity. Many other factors, however, may contribute to thrombotic diathesis in SLE. ${ }^{8}$

LA still appeared strongly correlated to thrombotic events, particularly arterial ones, but its association with livedo reticularis was not confirmed. Conversely, no difference in the prevalence of both IgG and IgM aCL between aPL positive patients with or without complications was observed, thus suggesting the low specificity of aCL detected by ELISA as a risk factor for the occurrence of aPL-related events in SLE. ${ }^{61315}$ Moreover, we investigated whether or not the definition of aCL level could have some clinical value (figure). We found that the mean level of $\operatorname{IgG}$ aCL was significantly higher in patients with arterial thrombosis than in those without any complication ( $p=0.002)$, whereas, no significant difference was found in the IgM aCL mean level.
In conclusion, LA is the most specific parameter for the diagnosis of thrombotic complications due to aPL in patients with SLE; both IgG and IgM aCL are not specific for aPL-related events. In addition, the measurement of IgG aCL level seems to be a valuable requirement before attributing clinical value to aCL positivity.

1 Asherson R A, Khamashta M A, Ordi-Ros J, et al. The 'primary' antiphospholipid syndrome: major clinical and serological features. Medicine 1989; 68: 366-74.

2 Harris E N, Gharavi A E, Hughes G R V. Anti-phospholipid antibodies. Clin Rheum Dis 1985; 11: 591-609.

3 Doria A, Ruffatti A, Calligaro A, Del Ross T, Ghirardello A, De Zambiasi P, Gambari P F. Antiphospholipid A, De Zambiasi P, Gambari P F. Antiphospholipid antibodies in mixed connec

4 Love P E, Santoro S A. Antiphospholipid antibodies: anticardiolipin and the lupus anticoagulant in systemi lupus erythematosus (SLE) and in non-SLE disorders. Ann Int Med 1990; 112: 682-98.

5 Alarcon-Segovia D, Deleze' M, Oria C V, et al Antiphospholipid antibodies and the antiphospholipid syndrome in systemic lupus erythematosus. A prospective analysis of 500 consecutive patients. Medicine 1989; 68; 353-65.

6 Sturfelt G, Nived O, Norverg R, Thorstensson R, Krook K. Anticardiolipin antibodies in patients with systemic lupus Anticardiolipin antibodies in patients with systemic

7 Weidmann C E, Wallace D J, Peter J B, Knight P J, Bear $M$ B, Klinenberg Jr. Studies of IgG, IgM and IgA antiphospholipid antibody isotypes in systemic lupu erythematosus. $\mathcal{F}$ Rheumatol 1988; 15: 74-9.

8 Harris E N. Solid-phase anti-cardiolipin test revisited. $\mathrm{Am}$ f Med 1988; 85: 599-601.

9 Ishii $Y$, Nagasawa K, Mayumi T, Niho Y. Clinical importance of persistence of anticardiolipin antibodies in systemic lupus erythematosus. Ann Rheum Dis 1990; 49: systemic

10 Out H J, Van Viliet M, de Groot P G, Derksen R H W M. Prospective study of fluctuations of lupus anticoagulant activity and anticardiolipin antibody titre in patients with systemic lupus erythematosus. Ann Rheum Dis 1992; 51: 353-57.

11 Thiagarajan P, Pengo V, Shapiro S. The use of the dilute Russell viper venom time for the diagnosis of lupus anticoagulants. Blood 1986; 4: 869-74.

12 Gharavi A E, Harris E N, Asherson R A, Hughes G R V. Anticardiolipin antibodies: isotype distribution and phospholipid specificity. Ann Rheum Dis 1987; 46: 1-6.

13 Derksen R H, Hasselaar O, Blokziil L, Gmeling Meyling F $H$, de Groot P G. Coagulation screen is more specific than the anticardiolipin antibody ELISA in defining a thrombotic subset of lupus patients. Ann Rheum Dis 1988; thrombotic sub

14 Vogel J J, Reber G, de Moerloose P. Laboratory and clinical features in systemic lupus erythematosus patients with or without anticardiolipin antibodies. Thromb Res 1991; 62: 545-56.

15 McHugh N J, Moye D A H, James I E, Sampson M, Maddison P J. Lupus anticoagulant: clinical significance in anticardiolipin positive patients with systemic lupus erythematosus. Ann Rheum Dis 1991; 50: 548-52. 